\title{
Development of a risk assessment method for sea trout in coastal areas exploited for aquaculture
}

\author{
Bengt Finstad $^{1, *}$, Anne D. Sandvik ${ }^{2}$, Ola Ugedal ${ }^{3}$, Knut W. Vollset ${ }^{4}$, Ørjan Karlsen ${ }^{2}$, \\ Jan G. Davidsen ${ }^{5}$, Harald Sægrov ${ }^{6}$, Robert J. Lennox ${ }^{4}$ \\ ${ }^{1}$ Norwegian University of Science and Technology, Department of Biology, 7491 Trondheim, Norway \\ ${ }^{2}$ Institute of Marine Research, PO Box 1870, 5817 Bergen, Norway \\ ${ }^{3}$ Norwegian Institute for Nature Research, Høgskoleringen 9, 7034 Trondheim, Norway \\ ${ }^{4}$ NORCE Norwegian Research Centre, Laboratory for Freshwater Ecology and Inland Fisheries, Nygårdsgaten 112, \\ 5008 Bergen, Norway \\ ${ }^{5}$ Norwegian University of Science and Technology, Department of Natural History, 7491 Trondheim, Norway \\ ${ }^{6}$ Rådgivende Biologer AS, Edvard Griegs vei 3, 5059 Bergen, Norway
}

\begin{abstract}
The regulation of aquaculture production in Norway considers the potential impact of salmon lice on wild fish. However, most attention has been focused on impacts on wild Atlantic salmon, despite the fact that anadromous brown trout spend the majority of their marine phase in coastal waters, where salmon lice have the highest impact. In the present study, we first suggest changes in marine living area and marine feeding time as sustainability indicators for first-time migrant sea trout, as high salmon lice densities may exclude sea trout from otherwise usable habitat and force them to return early to freshwater. Further, a method based on a bio-hydrodynamic model was developed to serve as a proxy for these indicators. The method accounted for the size, migration timing and spatial extent of sea trout and was demonstrated in 2 Norwegian salmon aquaculture production areas, Hardangerfjord (PO3) and Romsdalsfjord (PO5), and 2 focal rivers from within each fjord. Based on these comparisons, we exemplify how the change in marine living area and marine feeding time differed between PO3 and PO5 and within the areas. Sea trout migrating to sea late (June 5) were always more affected by lice than those migrating early (April 24) or at intermediate dates (May 15). Our estimates revealed dramatic potential impacts of salmon lice on sea trout populations, which were greatly influenced by spatial and temporal aspects. Considering the negative impacts of salmon lice on sea trout, a holistic view of environmental interactions between aquaculture and wild species that depend on habitats exploited for production is necessary.
\end{abstract}

KEY WORDS: Salmonids $\cdot$ Sea trout $\cdot$ Salmo trutta $\cdot$ Salmon lice $\cdot$ Aquaculture $\cdot$ Reduced marine living area $\cdot$ Reduced marine feeding time $\cdot$ Traffic light system

\section{INTRODUCTION}

Aquaculture of fish is broadly viewed as an industry contributing to economic development in rural areas (Bostock et al. 2010). However, the industry is increasingly under scrutiny regarding the environmental costs, such as pollution, biological invasions and proliferation of pathogens (Naylor et al. 2005, Taranger et al. 2015, Fjørtoft et al. 2019). Open net pen aquaculture of farmed Atlantic salmon Salmo salar and rainbow trout

${ }^{*}$ Corresponding author: bengt.finstad@ntnu.no
Oncorhynchus mykiss has been particularly scrutinized to identify and mitigate negative impacts (Liu et al. 2011). Growth in Norwegian aquaculture is regulated based on key sustainability indicators that govern the status of operations in 13 geographic regions (Vollset et al. 2018). A key sustainability indicator is the spread of salmon lice Lepeophtheirus salmonis in the marine environment; aquaculture development is directly linked to increased salmon lice abundance and high salmon lice densities resulting in mortality or reduced fitness of 
wild salmonid populations (Thorstad et al. 2015, Vollset et al. 2016, Fjørtoft et al. 2017). Monitoring of lice density and the response of wild hosts is therefore a key priority for environmental management and industry sustainability (Sandvik et al. 2020).

Research has catalyzed improvements to aquaculture operations, including combining aspects of traditional and modern practice, developing better management practices (BMPs) and selecting sites more effectively so that farms remain within the carrying capacity of inland and coastal water bodies (Edwards 2015). However, most of the attention has been focused on negative impacts of aquaculture on wild Atlantic salmon, with less consideration given to potential effects on anadromous brown trout Salmo trutta, also known as sea trout (Thorstad et al. 2015). Salmon lice can be lethal to sea trout but can also have sublethal effects, such as truncating growth by reducing time spent or space used in the marine environment (Birkeland 1996, Thorstad et al. 2015, Eldøy et al. 2020).

Brown trout are found throughout coastal Europe (MacCrimmon \& Marshall 1968, Ferguson et al. 2019). They are partial migrants, where some individuals (sea trout) migrate to sea while other remain resident in freshwater, and exhibit relatively high phenotypic plasticity (Caballero et al. 2012, Peiman et al. 2017, Nevoux et al. 2019). Sea trout typically exit rivers in the spring and feed on invertebrates and other fish in the upper water column (Thorstad et al. 2016, Davidsen et al. 2017). Many trout remain in the river estuary or in close proximity to the river, but movement up to 20 or $30 \mathrm{~km}$ away is also common (Davidsen et al. 2014, Eldøy et al. 2015, Atencio et al. 2021). Sea trout may be especially vulnerable to lice given that they spend so much time in coastal environments where planktonic salmon lice are distributed, and the potential habitat available to them may be reduced if they must avoid high risk areas where lice are abundant (Finstad \& Bjørn 2011, Thorstad \& Finstad 2018). Affected individuals can medicate against salmon lice by returning early to fresh or brackish water that lice cannot tolerate (Birkeland \& Jakobsen 1997, Serra-Llinares et al. 2020); however, this reduces the time they spend feeding at sea. Many sea trout populations have been observed to be greatly impacted by the effects of salmon lice and there is a clear need to develop risk assessments for implementing policy to protect sea trout populations. Direct measurement of lice densities in the water or lice induced mortality in wild salmonids is difficult to achieve; thus, several high quality and welldocumented proxies for environmental sustainability have been developed and used in the Norwegian 'traffic light system' (Vollset et al. 2018).
Biophysical models of salmon lice dispersion in coastal environments have reached a consensus in terms of constituents and parameterizations, and are widely used in salmon producing countries (Gillibrand \& Willis 2007, Adams et al. 2012, Salama et al. 2013, Asplin et al. 2014, 2020, Johnsen et al. 2014, 2016, Sandvik et al. 2016, 2020, Myksvoll et al. 2018, 2020). Salmon lice densities are modelled hourly across Norway, with publicly available values published weekly (www.lakselus.no), which can be applied to estimate the risk of negative impacts of salmon lice on sea trout. Given high resolution environmental forcing and reliable data from the industry, well-defined and suitable models can now be used for management purposes.

In the present paper, we demonstrate how results from biophysical models can be used to develop proxies for risk assessment by predicting consequences of salmon lice densities on marine feeding space or marine residence time of sea trout. Importantly, our method does not calculate direct salmon lice-induced wild fish mortality. Reduced marine living area (RML) is a function of the size of the marine area, the size of first-time migrants (i.e. the most vulnerable life stage), the marine residence time of first-time migrants and the habitat quality threshold for sea trout. Norway has thousands of sea trout rivers and streams, of which 430 have been mapped to understand sea trout populations and habitat (Anonymous 2019). To illustrate the method, we focus on 4 rivers in 2 production areas in which the impact of salmon lice on wild sea trout populations varies. A similar assessment could be made for all production areas, sea trout rivers or populations. The method can easily be used in other countries (e.g. Gargan et al. 2016a,b, Shephard et al. 2016, Eldøy et al. 2020) where similar biophysical models (Adams et al. 2016, Rabe et al. 2020) have been implemented to determine density of lice larvae in the water masses.

\section{MATERIALS AND METHODS}

\subsection{Defining model inputs}

\subsubsection{Model regions}

The coast of Norway is divided into aquaculture production zones (POs), based on an analysis of the dispersion of lice between aquaculture sites. The borders between zones were drawn to reflect boundaries across which there was limited lice dispersal (Ådlandsvik 2015). This implies that lice released 
from farms within a PO will likely stay within it, minimizing transfer of lice between POs. We used model results from 2 production areas, PO3 and PO5. PO3 is in western Norway and covers the area from Karmøy to Sotra, including the Hardangerfjord and Bjørnafjord. PO5, Stadt to Hustadvika, north of western Norway, incorporates the Storfjord and Romsdalsfjord. Each area has multiple rivers inhabited by sea trout and marine areas that are important feeding grounds (Anonymous 2019). The estimated numbers of sea trout rivers are 18 (Hardangerfjord) and 2 (Bjørnafjord) for PO3, and 47 for the entirety of PO5. Two model rivers from each PO were selected to exemplify how the method can be used: Oselvo and Etne from PO3 (see Fig. 1), and Eira and Rauma from PO5 (see Fig. 3).

\subsubsection{Size at first migration}

Size at the first seaward migration (smolt) is variable among populations and is a function of genetics and environmental pressures that control the feeding and growth of young sea trout. Geographic and hydrological features also play a role, with smaller sizes at smoltification in southern Norway $($ mean $=14 \mathrm{~cm}, 25 \mathrm{~g})$ than in the north $($ mean $=18 \mathrm{~cm}$, 50 g; L'Abée-Lund et al. 1989), and rivers with lakes tend to produce larger smolts because of the growth opportunities afforded to parr living in the lakes. Jonsson et al. (2001) observed trout as small as $7 \mathrm{~cm}$ smoltifying. Variations have been recorded as 14$29 \mathrm{~cm}$ (25-220 g; Vosso River; Jonsson 1985) and 1240 cm (15-600 g; Eids River, Urdal 2013). Mean length of sea trout smolts in two rivers of the Sognefjord (Aurland and Flåm) were 12.5 and $14.8 \mathrm{~cm}$, respectively. Smolts can become large but in general, sea trout move seaward when smaller than $20 \mathrm{~cm}$, and the average size is around $14 \mathrm{~cm}(25 \mathrm{~g})$. A stay of $8 \mathrm{wk}$ at sea typically achieves a size of approximately $24 \mathrm{~cm}$ $(110 \mathrm{~g})$. The lice burden depends upon the size of the fish, and we recognize it will vary. The value for the simulated smolt in our model was set to $60 \mathrm{~g}$, larger than the average size at outmigration, based on the assumption that smolts may spend some time growing in the marine environment before encountering lice.

\subsubsection{Timing of outmigration}

Sea trout predominantly migrate out of freshwater in spring, coincident with increases in water flow and temperature, but there is also a poorly understood au- tumnal migration (Davidsen et al. 2018, 2019, BirnieGauvin et al. 2019). The precise timing is a function of temperature, such that northern watercourses generally express a later migration (Jensen et al. 2012). The presence of lakes along rivers tends to prolong the outward migration period for sea trout. Spring migrants from lake systems in western, mid- and northern Norway typically leave in May (Flaten et al. 2016, Davidsen et al. 2018, Urke et al. 2018); however, migrants from smaller rivers and streams may leave earlier (Aldvén \& Davidsen 2017). Long-term data from smolt traps in western Norway have revealed the timing of $50 \%$ sea trout migration from 2001 to 2011 to be between May 10 and 22 (Skaala et al. 2014). In the Dale River (Osterfjord), the timing of $50 \%$ migration varied between May 10 and 26 in different years (Karlsen et al. 2016). Methods for enumeration can be subject to various biases depending on whether they are based on detections of fish that have been captured, handled and tagged, the placement of the enumeration device, the timing of monitoring (ideal to start early and finish late) and environmental conditions that influence vulnerability to capture. Instead of using a single migration date, we selected an early (April 24), medium (May 15) and late (June 5) migration timing, which should encompass the majority of spring migration timings expressed by sea trout in the POs studied.

\subsubsection{Residence time at sea}

Sea trout have highly flexible life histories: they can spend variable amounts of time at sea and even return to freshwater or estuaries intermittently. Duration of the sea sojourn is therefore difficult to calculate, and existing estimates emphasize the challenge of determining a clear number. The duration of marine residence has been estimated for the Tosenfjord (73 d), Vardnesvassdraget (70 d), Skjerstadfjord (55 d), Halsvassdraget (55 d), and Hemnfjord (38 d); in all cases much inter-individual variation was found (Berg and Berg 1989, Jensen et al. 2005, Davidsen et al. 2018, 2019). However, although the marine residence period can be longer (Jonsson \& Jonsson 2009), it typically occurs during the summer, between June and August. Therefore, we have used a marine residence period of $70 \mathrm{~d}$ in the model.

\subsubsection{Marine habitat of sea trout}

Sea trout are observed throughout fjord areas, but their distribution tends to be biased towards the near- 
shore, shallow water areas. Telemetry studies and trawl surveys have confirmed that sea trout prefer habitat close to the shoreline (Lyse et al. 1998, Thorstad et al. 2007). Many trout will remain close to their home river estuary, but some can travel long distances (Berg \& Berg 1987, Finstad et al. 2005, Thorstad et al. 2007, Middlemas et al. 2009, Davidsen et al. 2014, del Villar-Guerra et al. 2014, Aldvén et al. 2015). Larger veteran fish which have migrated in previous years, may be more likely to venture further from their home rivers (Davidsen et al. 2018, 2019, Eldøy et al. 2021). Salmon lice have a surface-oriented vertical distribution in the water column, meaning that sea trout depth affects their potential exposure. Post-smolts of sea trout are distributed in the upper water column (Lyse et al. 1998). Atencio et al. (2021) observed an average depth of $0.9 \mathrm{~m}$, and Urke et al. (2018) found all movements were within the top $2 \mathrm{~m}$ of water. The maximum depth reported is $7 \mathrm{~m}$ (Ruud 2015). Our simulated sea trout migration is therefore limited to an area no more than $20 \mathrm{~km}$ away from the river of origin and a maximum depth of $2 \mathrm{~m}$.

\subsubsection{Critical limits of salmon lice parasites}

Sea trout can tolerate some parasitism by salmon lice, but beyond critical densities the parasites can negatively impact the physiology of the fish and can be lethal. Marine areas with salmon lice densities beyond critical can be inhospitable to sea trout. Laboratory studies with experimental infestations have calculated critical density thresholds as follows: 1 louse $\mathrm{g}^{-1}$ for a $60 \mathrm{~g}$ post-smolt trout (Bjørn \& Finstad 1997), 13 adult/pre-adult lice per trout smolt

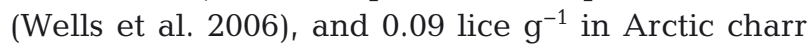
(Fjelldal et al. 2019). Effects of interest are mortality or early return due to lice infestations in sea trout before completing a sufficient feeding period in the ocean. Taranger et al. (2015) developed an index of effect for salmon lice based on fish weight that is followed in this study based on the $60 \mathrm{~g}$ fish size decided upon above. The Taranger et al. (2015) index using the size as described above corresponds to 18 lice per individual as critical $(100 \%$ fish affected by lice), $50 \%$ affected at 12-18 lice per individual, $20 \%$ at $6-12$ lice per individual, and $0 \%$ below 6 lice per fish).

Not all lice attached to smolts will survive and impact the fish. Laboratory studies of salmon lice survival have observed $60 \%$ survival of lice (Grimnes \& Jakobsen 1996, Bjørn \& Finstad 1997, 1998). There- fore, we adjusted the estimates of Taranger et al. (2015) to create a simplified matrix of impact: $100 \%$ impact for $>30$ lice, 50\% impact for 10-30 lice, and no impact for 10 or fewer lice.

\subsubsection{Salmon lice density}

The density of infective salmon lice was computed with the bio-hydrodynamic lice dispersion model described in e.g. Johnsen et al. (2014, 2016), Myksvoll et al. (2018), Sandvik et al. (2016, 2020), where an individual based model (IBM) with known behaviour and development (from the non-infective nauplii to the end of the infectious copepodid stage) for salmon lice was implemented within the Norwegian coastal current model (Albretsen et al. 2011, Asplin et al. 2020, Dalsøren et al. 2020). Environmental conditions such as light, salinity, temperature and water currents all have an important role in determining the proliferation of salmon lice and the IBM is regularly updated with new knowledge to better describe the demography of salmon lice and improve understanding of how they spread in the water masses and between salmonid hosts.

All Norwegian active farms are obligated to regularly report several variables: the number of fish (on a monthly basis), the temperature at $3 \mathrm{~m}$ depth and the number of adult female lice per fish (on a weekly basis). Thus, realistic numbers of nauplii released from each aquaculture site can be computed based on Stien et al. (2005) and included as the source term in the bio-hydrodynamic model (Myksvoll et al. 2018). Forcing for the dispersion model (currents, temperature and salinity) was provided by a hydrodynamic fjord model with a horizontal resolution of $160 \times 160 \mathrm{~m}$, and 35 vertical sigma layers (Skarðhamar et al. 2018, Dalsøren et al. 2020). The output from the model is hourly numbers of salmon lice larvae in each $160 \times 160 \mathrm{~m}$ grid square.

A warning system for areas with elevated lice infestation pressure was first presented in Sandvik et al. (2016) and further developed in Sandvik et al. (2020) and is now part of the Norwegian traffic light management system (Vollset et al. 2018). What constitutes elevated lice infestation pressure, however, is linked to the size of the impacted fish, as described in Taranger et al. (2015). To determine where lice density poses an unacceptably high risk of mortality for a $60 \mathrm{~g}$ wild sea trout, model values corresponding to the limits given in Section 2.1.6 were estimated using the relative operating characteristic (ROC) method described in Sandvik et al. $(2016,2020)$. The number 
of lice larvae in each grid is used to calculate how many sea lice would infest a trout remaining in that location for a given amount of time.

The ROC is a graph of the hit rate, $\mathrm{H}$, against the false alarm rate, $\mathrm{F}$, for different decision thresholds (Mason 1982), developed based on observations of salmon smolts in sentinel cages in the Hardangerfjord between the years 2012 and 2017. We assumed that the natural residence time for sea trout in the fjords was $70 \mathrm{~d}$. To cover the migration period, an early, normal and late migration (April 24, May 15 and June 5) were considered.

Within each PO, there are several sea trout populations. For management purposes, it can be appropriate to consider all populations as one cohort, but it can also be appropriate to consider each river separately. The benefits of using a model method rather than in situ observations is that the area to be assessed can be defined differently depending on whether the question is the impact in an entire production area or for a single river or population. In the present work, examples are given for (1) two POs, where all inshore water was assumed to be the area of residence, and (2) individual rivers, where $20 \mathrm{~km}$ from the river mouth was defined as the marine living area.

Reduced marine living area (RML) and reduced marine feeding time (RMT), putatively damaging to the fitness of sea trout, were defined as:

$$
\mathrm{RML}=([\text { red area }]+[\text { yellow area } \times 0.5]) / \text { total area }
$$

where red area and yellow area are the size of the red and yellow areas (Fig. 1), respectively. The colors indicate the impact (Section 2.1.6) when the number of infective copepods is summarized over the $70 \mathrm{~d}$ of natural residence time for sea trout. According to Eq. (1) it is assumed that all red areas and $50 \%$ of yellow areas are lost due to salmon lice infestation pressure before $70 \mathrm{~d}$ have elapsed. We have therefore calculated the infestation pressure cumulatively and defined RMT as the difference between the number of days until RML exceeds $30 \%$ and the natural marine residence time of $70 \mathrm{~d}$ :

$$
\text { RMT = number of days until RML }>30 \%-70 \mathrm{~d}
$$

15 May-24 Jul 2019

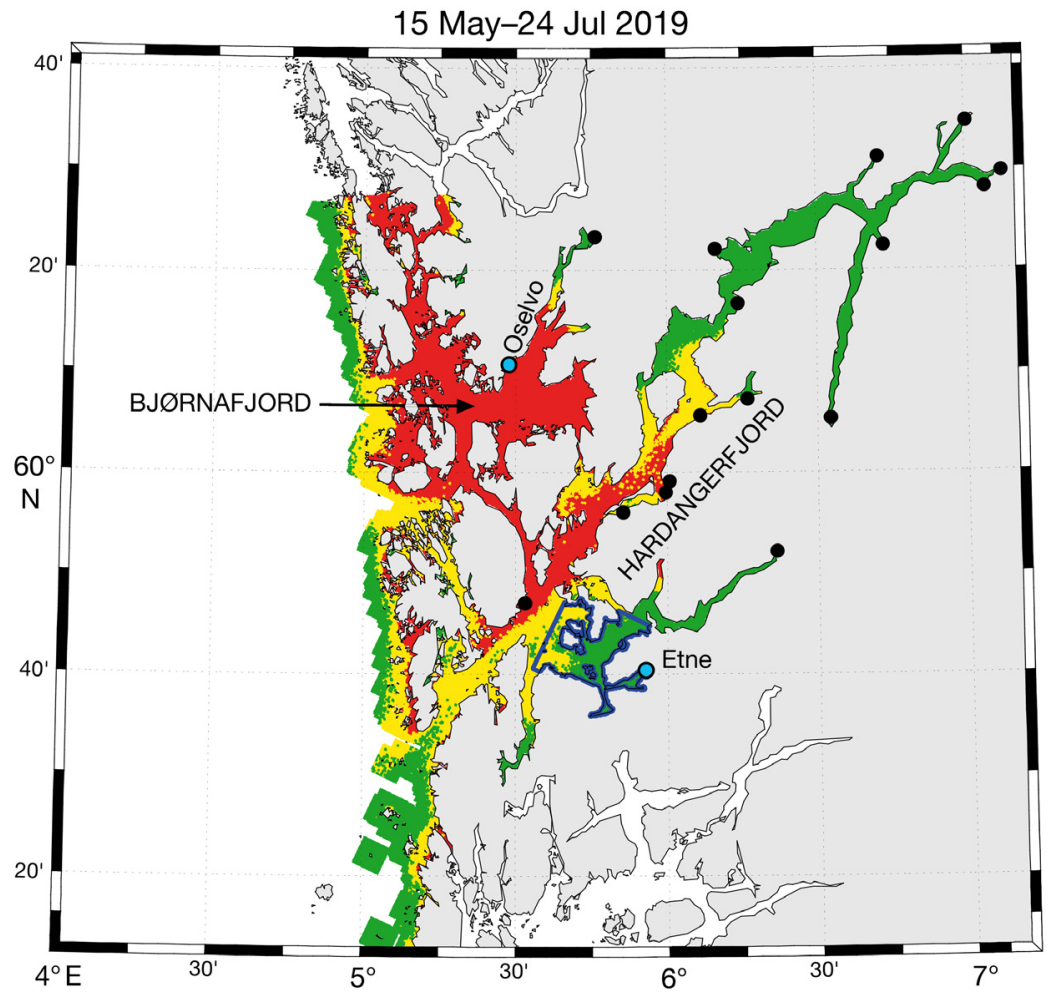

Fig. 1. A relative operating characteristic (ROC) map of PO3 showing where it expected that intermediate sea trout smolt migrants (remaining in the area and Etne rivers are marked with cyan dots. The marine living area for Etne sea trout, defined as $20 \mathrm{~km}$ from the home river mouth, is outlined in blue

\section{RESULTS}

\subsection{PO3}

Due to a combination of seasonal variation in the water temperature and and the Norwegian regulations (Sandvik et al. 2021) with lower legal lice levels on farmed fish during the smolt migration period, the number of salmon lice larvae hatched is strongly seasonal (Sandvik et al. 2021), with minimum numbers in spring (before the peak salmon smolt migration) and maximum numbers in early autumn (when the water temperature is at its yearly maximum). Thus, sea trout that migrate later are more affected by lice than early migrants. RML for intermediate migrants was estimated to be $49 \%$ (Figs. 1 \& 2), while it was estimated to be $32 \%$ and $66 \%$ for early and late migrants, respectively, in PO3. When comparing the impact from salmon sea lice on sea trout in the 2 focal rivers in $\mathrm{PO} 3$, Oselvo in the Bjørnafjord was much more negatively impacted than Etne. RML for sea trout from Oselvo was reduced by 94,97 and $98 \%$ for 
early, intermediate and late migrants, respectively. In comparison, RML for trout from Etne was reduced by 0,17 and $68 \%$. Marine time was significantly reduced for late migrants from Etne only (RMT $=-16 \mathrm{~d})$, whereas all migrants from Oselvo had reduced marine time (early migrants: $-30 \mathrm{~d}$, intermediate migrants: $-46 \mathrm{~d}$, late migrants: $-56 \mathrm{~d}$ ).

\subsection{PO5}

Similar to PO3, late RML was more negatively affected than early $\mathrm{mi}-$ grants in PO5, increasing from $34 \%$ for early migrants to 45 (Figs. $3 \& 4$ ) and $59 \%$ for intermediate and late migrants, respectively. The 2 rivers selected for analysis in this region both originate in the same fjord but fish from these rivers showed different RML and RMT. Sea trout from Eira were much more dramatically affected by salmon lice regardless of

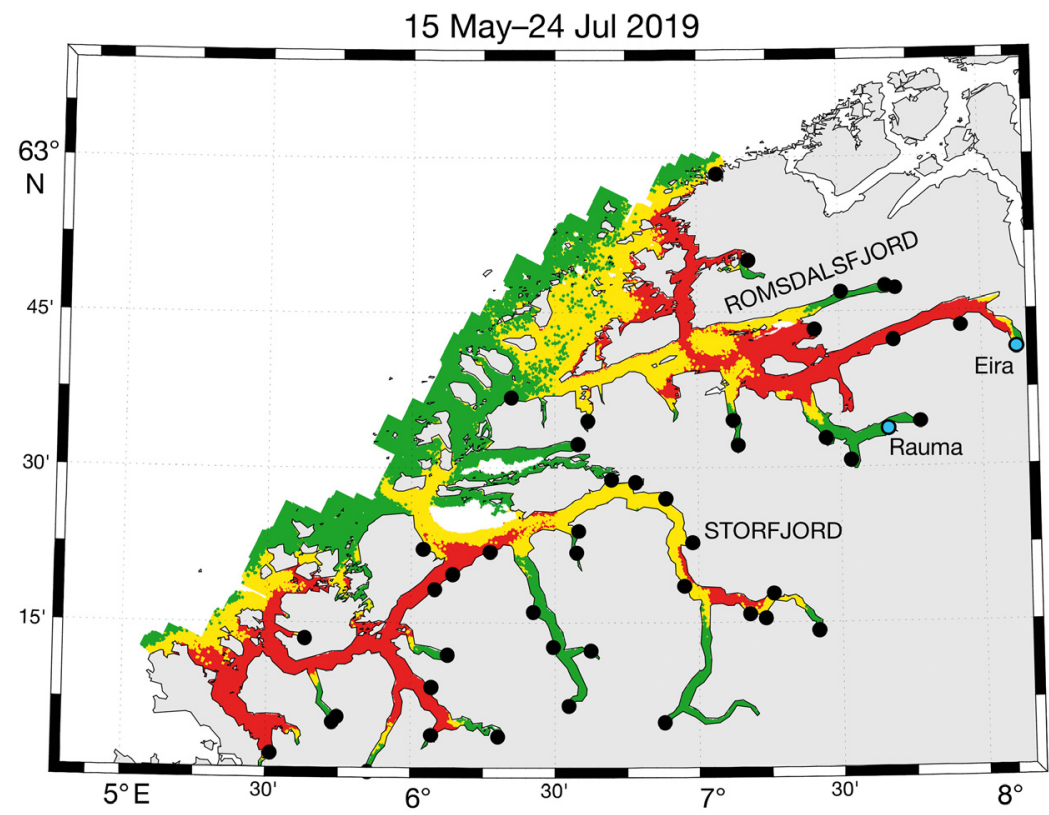

Fig. 3. ROC map of PO5 showing where it is expected that intermediate sea trout smolt migrants (remaining in the area from May 15 to July 24) are infested with $>18$ mobile lice (red area), between 6 and 18 mobile lice (yellow area) and $<6$ mobile lice (green area). The locations of the 47 sea trout rivers in the PO are marked with black dots, and the Eira and Rauma rivers are marked with cyan dots migration timing, with 83,87 and $85 \%$ RML for early, intermediate, and late migrants, compared to 40,43 and $48 \%$ RML for sea trout from Rauma. These values corresponded to very short marine residence times for Eira trout $(\mathrm{RMT}=-19$,

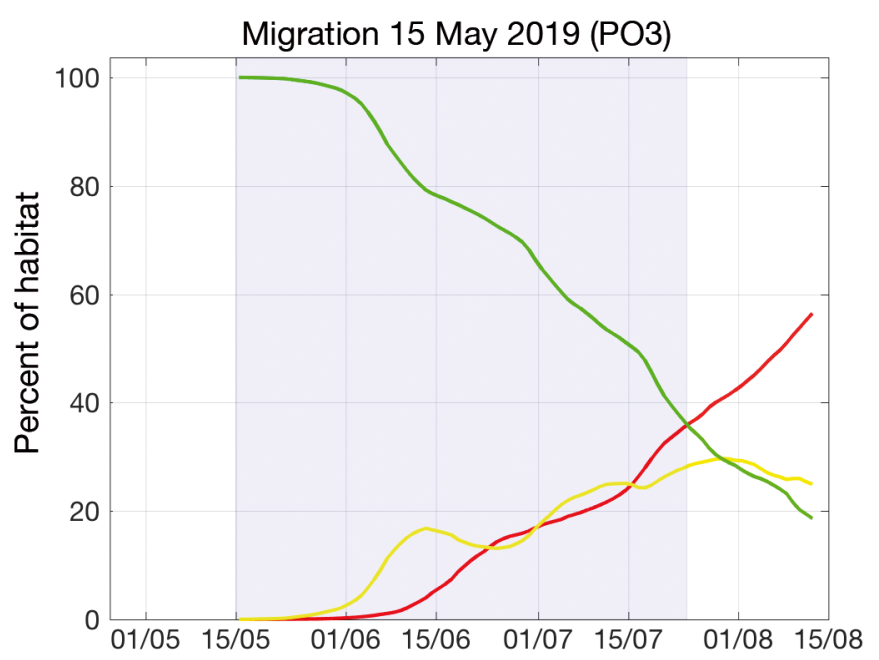

Fig. 2. Estimated percent of total marine living area in $\mathrm{PO} 3$ where sea trout smolt are likely to be infested with $>18$ mobile lice (red line), between 6 and 18 mobile lice (yellow line) and $<6$ mobile lice (green). The blue shaded area indicates a period of $70 \mathrm{~d}$ starting on an intermediate migration date

(May 15), the same period shown in Fig. 1

$-35,-50$ d) and more modest, albeit still drastic, reductions in marine residence time for Rauma trout $(\mathrm{RMT}=-6,-24,-40 \mathrm{~d})$.

\section{DISCUSSION}

Feeding migration enhances the growth and lifetime reproductive potential of some coastal fish species (Chapman et al. 2012). Partial migration in brown trout, specifically, is an adaptation to optimize the growth of individuals, with positive consequences for population-level reproductive potential (Bohlin et al. 2001, Peiman et al. 2017). As sea trout are inherently more coastal dwelling than Atlantic salmon, they may be more susceptible to habitat loss in coastal areas and should be a focus of conservation efforts when considering the negative impacts of salmon lice in coastal environments.

Modeling RML and RMT as sustainability indicators for first-time migrant sea trout looks promising. Further, the model used to estimate the spread of salmon lice has previously been validated and applied in multiple other studies (Sandvik et al. 2016, 2020, Myksvoll et al. 2018). Although the model will continue to undergo refinement, it provides a versa- 


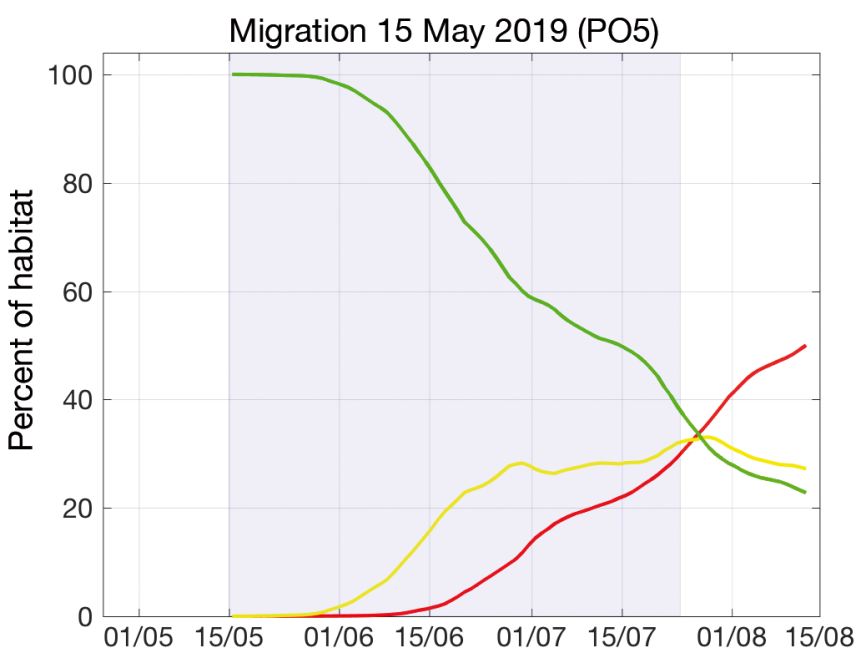

Fig. 4. Estimated percent of total marine living area in PO5 where sea trout smolt are likely to be infested with $>18$ mobile lice (red line), between 6 and 18 mobile lice (yellow line) and $<6$ mobile lice (green line). The blue shaded area indicates a period of $70 \mathrm{~d}$ starting on an intermediate migration date (May 15), the same period shown in Fig. 3

tile tool for estimating the phenology and demography of salmon lice originating from farmed fish in fjords and coastal waters. We used a newer high-resolution model with a $160 \times 160 \mathrm{~m}$ grid to evaluate environmental parameters, which should enhance performance, although this resolution is not as widely validated as the $800 \times 800 \mathrm{~m}$ grid used in previous model estimates. The warning system in areas with elevated lice infestation pressure (Sandvik et al. 2016, 2020) is part of the Norwegian traffic light management system (Vollset et al. 2018) and is here further developed to be suitable for sea trout.

It was important to include variability and conservative estimates in the method to account for the highly plastic life history of sea trout (Klemetsen et al. 2003, Thorstad et al. 2015, Nevoux et al. 2019). However, additional information about behaviour and phenotypic plasticity is needed to better account for behavioural adaptations to exposure to salmon lice. Accounting for such variation provides reasonable range limits that can be used to develop advice for management of industry and policy.

Although telemetry studies have revealed that some individuals will stray further and deeper, the majority of detections suggest that sea trout tend to frequent shallow littoral habitats and spend time close to the surface when in the marine environment. The model parameters describing potential sea trout habitat were reasonably conservative to account for variation and still showed drastic reductions in the livable area available to trout as a result of salmon lice parasite pressure. Sea trout can take refuge from salmon lice by moving from marine habitat back into rivers (Nevoux et al. 2019), but this negatively affects growth and is likely an emergency behaviour to deal with critical lice loads. High loads of lice reduce the growing time of sea trout by forcing them to move out of the marine environment prematurely, and for the 4 rivers discussed in the present work we found that some populations of trout had the length of their marine sojourn reduced by up to $71 \%$ (late migrants modeled for the Eira River). An alternative to leaving the marine habitat is to move vertically into stratified freshwater close to the surface. This strategy has been observed in sea trout with restricted horizontal movement (Mohn et al. 2020), but most likely increases the susceptibility of individuals to predation as they are more exposed to visual predators, including birds. This increase in predation mortality is hard to quantify, but likely varies spatially and seasonally.

The impact of salmon lice on RML and RMT will vary widely between rivers, as can be seen by picturing a $20 \mathrm{~km}$ radius around the 18 rivers marked with black dots in Fig. 1. For example, sea trout from rivers Oselvo and Etne will migrate into a relatively large area with marine water influence (Fig. 1). In contrast, for rivers in the inner regions of the fjord, the area within $20 \mathrm{~km}$ of the river mouth will encompass a narrow region with high freshwater influence. Consequently, in this method, because the inner part of the fjords might be partly shielded from lice by freshwater influence, trout populations from these areas will generally be much less impacted by lice than populations in the outer fjords. However, high productivity marine habitat in the outer fjords is accessible to trout from inner fjord populations and vice versa. Consequently, it is important that these things are considered holistically when using the results from this risk assessment model.

Critical threshold values for salmon lice parasitism are an active area of research. Presently, the model used values based on laboratory work by Taranger et al. (2012), but these values do not necessarily represent the situation among wild fish in the field. Holding can stress fish and treatment effects may be exacerbated by the additional effects of handling and confinement (Wendelaar Bonga 1997). Ascertaining values from wild fish is difficult, but cameras could be used to survey lice numbers on wild fish and develop metrics for estimating fish health from behaviour on camera. However, such methods are subject to survivor bias and will still not likely represent the authentic threshold values needed for modelling. 
Refinement of laboratory experiments to build on those of Taranger et al. (2012) will therefore be useful to develop more confident estimates of lice impacts on sea trout survival. A recently published study by Fjelldal et al. (2020) exemplifies that although estimates of mortality impact of salmon lice in laboratory studies vary, physiological measurements of stress, including osmoregulatory stress, in salmonids are fairly predictable. Consequently, laboratory studies can be used to define critical thresholds where fish will experience physiological imbalances, which are likely to affect sea trout behaviour and survival.

Numerous studies have demonstrated that elevated levels of salmon lice due to fish farms may impact the life history and marine growth of sea trout. For example, Shephard et al. (2016) demonstrated that condition of sea trout was a function of distance from active farms. A recent study by Serra-Llinares et al. (2020) elegantly demonstrated how salmon lice impact the survival and marine habitat residency of sea trout. This was performed by infesting sea trout with salmon lice, releasing trout in an area with naturally low salmon lice densities and comparing tagged individuals to tagged uninfested individuals. This randomized control trial setup revealed that sea trout infested with an average of 65 lice per fish had a hazard ratio of 2.7, and reduced their marine residence time from 100 to $18 \mathrm{~d}$. Although 65 lice per fish is a relatively high level of infestation, similar levels are readily observed during surveillance of sea trout in Norwegian fjords with high lice densities, so this level of infestation is biologically relevant. The study is thus aligned with the modelling exercise presented in this study and supports the conclusion that salmon lice can strongly reduce the ability of sea trout to utilize the marine environment when infestation pressure is high. It also indicates that direct mortality of sea trout may be large even though they can behaviourally adapt to lice infestations.

This analysis did not directly model mortality of fish exposed to salmon lice. The model was parameterized such that sea trout would be expected to return to freshwater when livable area was reduced beyond a threshold, but these fish do not necessarily survive. Reduced marine habitat increases competition for limited resources and has negative impacts on the potential production of sea trout by causing density-dependent mortality. Moreover, premature return to freshwater also likely reduces the survival of sea trout given that they expend much energy undergoing smoltification and swimming long distances without the payoff of rich marine feeding opportunities. The large potential reductions in mar- ine living area and marine residence time suggest overwhelmingly negative impacts of salmon lice on the production of sea trout, which have manifested in population declines in regions such as the Hardangerfjord (Skoglund et al. 2019). The mechanisms for the declines are well understood and now empirically demonstrated in the model presented in this analysis.

\subsection{Important biological aspects to consider in further work}

In the present study, a lice mortality rate of $40 \%$ between sessile and mobile lice stages is assumed. However, this rate is based on a small number of laboratory experiments. Recaptures of artificially infested fish in areas without lice can clarify whether this also applies in nature. Alternatively, one can model the effects of various lice mortality rates on the fish and consider the extent to which categorization (Section 2.1.6) changes. So far, these data are based on first-time migrants, but marine time may also be reduced for veteran migrants infested with lice and RMT can then accumulate across several years. Such scenarios can be modeled with data on salmon liceinduced mortality and survival after premature returns. In this modeling, a fixed size of $60 \mathrm{~g}$ has been set for first-time migrant sea trout, but the size distribution of first-time migrants varies among populations, and this should be considered in further calculations. We also assume that sea trout returning prematurely to freshwater do not return to sea within the same year. However, data from preliminary experiments show that some trout migrate back to sea after getting rid of lice and then return to the watercourse a second time. A recent study (Bui et al. 2018) found that sea trout previously infested with salmon lice have lower numbers of lice in later infestations. If these results are generalizable, salmon lice infectivity should be adjusted downward during the season. Further research must clarify this. Premature return does not mean that the fish will necessarily survive. When sea trout return prematurely, they have experienced reduced marine feeding, and their energy reserves will therefore be lower and possibly insufficient to survive the winter. Similarly, it has been observed that sea trout with very high lice infestations die even when they return prematurely. The above illustrates a need for a better description of the importance of premature return, physiological effects and mortality, as a function of number of lice per fish. 


\subsection{Important aspects of modeling}

To obtain a realistic description of the number of infectious salmon lice larvae per unit of area, it is important that environmental conditions (light, salinity, temperature and currents) are described in as much detail as possible. Our understanding of how various environmental conditions affect lice biology continues to expand, and new discoveries are continuously implemented in the lice model. Furthermore, it has been shown that the uncertainty in the model calculations of salmon lice larvae is reduced by including new and better knowledge about lice biology (Sandvik et al. 2020). Two resolutions of the model are available, one with a $800 \times 800$ m grid resolution, and one with a $160 \times 160 \mathrm{~m}$ grid resolution, which is used in this study. It is expected that smaller grid increments will improve the description of environmental conditions, and preliminary tests indicate that the differences between models are primarily local, and that the calibration done for the lower resolution model also applies to the higher resolution model. However, a more thorough assessment of the latter should be performed. In relation to the assessment of RML and RMT, a separate study should be conducted to test the sensitivity of the grid resolution. In the model used, the lice density in the upper $2 \mathrm{~m}$ of the water column was used. This is assumed to be adequate for the vertical feeding area of sea trout. However, the model's sensitivity to the choice of depth should be tested. As more knowledge on the behavior of sea trout is acquired, for example from telemetry experiments, it will be possible to perform a more sophisticated risk assessment by introducing these in our model. However, currently this simple approach provides a good estimate, especially when it comes to variability between trout stocks.

\section{CONCLUSIONS AND FURTHER WORK}

We conclude that the proposed indices (RML and RMT) are well suited for estimating the impact of salmon lice on sea trout populations, and that the model proxies for RML and RMT work as intended. The examples show that the method works and can be implemented for all production areas and in all rivers with known sea trout populations. It is also possible to implement new knowledge and conduct sensitivity analysis in the present method. Further, the method can easily be used in other countries (e.g. Gargan et al. 2016a,b, Shephard et al. 2016, Eldøy et al. 2020) where similar biophysical models (Adams et al. 2016, Rabe et al. 2020) have been implemented providing density of lice larvae in the water.

As the results have shown, the impact of lice on individual stocks within a production area can vary widely, and how to treat these differences in an overall assessment for each production area has not been considered. Similar to Atlantic salmon assessments (Vollset et al. 2018), it is therefore necessary to consider whether and how weighting of individual rivers should be implemented in a possible sustainability indicator for sea trout. Another important point is that the method does not calculate salmon liceinduced wild fish mortality but instead RML and RMT. Therefore, appropriate limits to set in order to use these indices as a sustainability indicator must be determined. One suggestion is to set the limit values to the same as the mortality limits used for Atlantic salmon (high impact: RML > 30\%; moderate impact: $10 \%>\mathrm{RML}<30 \%$ and low impact: RML < 10\%) based on the argument that sea trout are evenly distributed in the marine environment.

Acknowledgements. This work was carried out with funding and support from the Ministry of Trade, Industry and Fisheries, the Norwegian Environment Agency, the Norwegian Food Safety Authority, the Norwegian Institute for Marine Research, the Norwegian Institute for Nature Research, the Norwegian Veterinary Institute, NORCE the Norwegian Research Centre, Rådgivende biologer and the Norwegian University of Science and Technology. B.F. also acknowledges financial support from DNV (Det Norske Veritas). The authors thank the traffic light initiative steering committee, led by Tor F. Næesje, Karin K. Boxaspen and Brit Hjeltnes, and other members of the traffic light system expert group: Frank Nilsen, Ingrid Ellingsen, Kari O. Helgesen, Lars Qviller, Sussie Dalvin, Mari S. Myksvoll, Peder A. Jansen and Anja B. Kristoffersen, as well as researchers who contributed to grey literature, discussions and meetings, too numerous to name individually here. The simulations were performed using resources provided by UNINETT Sigma2 - the National Infrastructure for High Performance Computing and Data Storage in Norway.

\section{LITERATURE CITED}

Adams T, Black K, MacIntyre C, MacIntyre I, Dean R (2012) Connectivity modelling and network analysis of sea lice infection in Loch Fyne, west coast of Scotland. Aquacult Environ Interact 3:51-63

Adams TP, Aleynik D, Black KD (2016) Temporal variability in sea lice population connectivity and implications for regional management protocols. Aquacult Environ Interact 8:585-596

Ådlandsvik B (2015) Forslag til produksjonsområder i norsk lakse- og ørretoppdrett. Rapport fra Havforskningen, no. 20-2015

Albretsen J, Sperrevik AK, Staalstrøm A, Sandvik AD, Vikebø F, Asplin L (2011) NorKyst-800 report no. 1: user 
manual and technical descriptions. IMR Res Rep Ser Fisken og Havet 2/2011. Institute of Marine Research, Bergen

Aldvén D, Davidsen JG (2017) Marine migrations of sea trout (Salmo trutta). In: Harris GS (ed) Sea trout: science \& management. Proc 2nd International Sea Trout Symp, October 2015, Dundalk, p 267-276

Aldvén D, Degerman E, Höjesjö J (2015) Environmental cues and downstream migration of anadromous brown trout (Salmo trutta) and Atlantic salmon (Salmo salar) smolts. Boreal Environ Res 20:35-44

Anonymous (2019) Klassifisering av tilstanden til 430 norske sjøørretbestander. Temarapport fra Vitenskapelig råd for lakseforvaltning nr. 7, Trondheim

Asplin L, Johnsen IA, Sandvik AD, Albretsen J, Sundfjord V, Aure J, Boxaspen KK (2014) Dispersion of salmon lice in the Hardangerfjord. Mar Biol Res 10:216-225

Asplin L, Albretsen J, Johnsen IA, Sandvik AD (2020) The hydrodynamic foundation for salmon lice dispersion modeling along the Norwegian coast. Ocean Dyn 70: 1151-1167

Atencio BJ, Thorstad EB, Rikardsen AH, Jensen JLA (2021) Keeping close to the river, shore, and surface: the first marine migration of brown trout (Salmo trutta) and Arctic charr (Salvelinus alpinus) post-smolts. J Fish Biol (Early View)

Berg OK, Berg M (1987) Migrations of sea trout, Salmo trutta L., from the Vardnes river in northern Norway. J Fish Biol 31:113-121

Berg OK, Berg M (1989) The duration of sea and freshwater residence of the sea trout, Salmo trutta, from the Vardnes River in northern Norway. Environ Biol Fishes 24:23-32

Birkeland K (1996) Consequences of premature return by sea trout (Salmo trutta) infested with the salmon louse (Lepeophtheirus salmonis Krøyer): migration, growth and mortality. Can J Fish Aquat Sci 53:2808-2813

* Birkeland K, Jakobsen PJ (1997) Salmon lice, Lepeophtheirus salmonis, infestation as a causal agent of premature return to rivers and estuaries by sea trout, Salmo trutta, juveniles. Environ Biol Fishes 49:129-137

Birnie-Gauvin K, Thorstad EB, Aarestrup K (2019) Overlooked aspects of the Salmo salar and Salmo trutta lifecycles. Rev Fish Biol Fish 29:749-766

Bjørn PA, Finstad B (1997) The physiological effects of salmon lice infection on sea trout post smolts. Nord J Freshw Res 73:60-72

Bjørn PA, Finstad B (1998) The development of salmon lice (Lepeophtheirus salmonis) on artificially infested post smolts of sea trout (Salmo trutta). Can J Zool 76:970-977

Bohlin T, Pettersson J, Degerman E (2001) Population density of migratory and resident brown trout (Salmo trutta) in relation to altitude: evidence for a migration cost. J Anim Ecol 70:112-121

Bostock J, McAndrew B, Richards R, Jauncey K and others (2010) Aquaculture: global status and trends. Philos Trans R Soc B 365:2897-2912

Bui S, Halttunen E, Mohn AM, Vågseth T, Oppedal F (2018) Salmon lice evasion, susceptibility, retention, and development differ amongst host salmonid species. ICES J Mar Sci 75:1071-1079

Caballero P, Morán P, Marco-Rius F (2012) A review of the genetic and ecological basis of phenotypic plasticity in brown trout. In: Polakof S, Moon TW (eds) Trout: from physiology to conservation. Nova Science, Hauppauge, NY, p 9-26
Chapman BB, Hulthén K, Brodersen J, Nilsson PA, Skov C, Hansson LH, Brönmark C (2012) Partial migration in fishes: causes and consequences. J Fish Biol 81:456-478

* Dalsøren SB, Albretsen J, Asplin L (2020) New validation method for hydrodynamic fjord models applied in the Hardangerfjord, Norway. Estuar Coast Shelf Sci 246: 107028

พ Davidsen JG, Daverdin M, Arnekleiv JV, Rønning L, Sjursen AD, Koksvik JI (2014) Riverine and near coastal migration performance of hatchery brown trout Salmo trutta. J Fish Biol 85:586-596

* Davidsen JG, Knudsen R, Power M, Næsje TF and others (2017) Trophic niche variation among sea trout Salmo trutta in Central Norway investigated by three different time-integrated trophic tracers. Aquat Biol 26:217-227

Davidsen JG, Eldøy SH, Sjursen AD, Rønning L and others (2018) Marine vandringer og områdebruk hos sjøørret og sjørøye i Tosenfjorden. NTNU Vitenskapsmuseet naturhistorisk rapport 2018-8:1-84, Trondheim

Davidsen JG, Eldøy SH, Meyer I, Halvorsen A and others (2019) Sjøørret og sjørøye i Skjerstadfjorden-Marine vandringer, områdebruk og genetikk. NTNU Vitenskapsmuseet naturhistorisk rapport 2019-5:1-83, Trondheim

del Villar-Guerra D, Aarestrup K, Skov C, Koed A (2014) Marine migrations in anadromous brown trout (Salmo trutta). Fjord residency as a possible alternative in the continuum of migration to the open sea. Ecol Freshw Fish 23:594-693

del Villar-Guerra D, Larsen MH, Baktoft H, Koed A, Aarestrup K (2019) The influence of initial developmental status on the life-history of sea trout (Salmo trutta). Sci Rep 9:13468

Edwards P (2015) Aquaculture environment interactions: past, present and likely future trends. Aquaculture 447: 2-14

Eldøy SH, Davidsen JG, Thorstad EB, Whoriskey F and others (2015) Marine migration and habitat use of anadromous brown trout (Salmo trutta). Can J Fish Aquat Sci 72:1366-1378

Eldøy SH, Ryan D, Roche WK, Thorstad EB and others (2020) Changes in growth and migration patterns of sea trout before and after the introduction of Atlantic salmon farming. ICES J Mar Sci 77:2623-2634

Eldøy SH, Bordeleau X, Lawrence MJ, Thorstad EB and others (2021) The effects of nutritional state, sex and body size on the marine migration behaviour of sea trout. Mar Ecol Prog Ser 665:185-200

Ferguson A, Reed TE, Cross TF, McGinnity P, Prodöhl PA (2019) Anadromy, potamodry and residency in brown trout Salmo trutta: the role of genes and the environment. J Fish Biol 95:692-718

Finstad B, Bjørn PA (2011) Present status and implications of salmon lice on wild salmonids in Norwegian coastal zones. In: Jones S, Beamish R (eds) Salmon lice: an integrated approach to understanding parasite abundance and distribution. Wiley-Blackwell, Oxford, p 281-305

* Finstad B, Økland F, Thorstad EB, Bjørn PA, McKinley RS (2005) Migration of hatchery-reared Atlantic salmon and wild anadromous brown trout post-smolts in a Norwegian fjord system. J Fish Biol 66:86-96

Fjelldal PG, Hansen TJ, Karlsen Ø, Wright DW (2019) Effects of laboratory salmon louse infection on Arctic char osmoregulation, growth and survival. Conserv Physiol 7:coz072 
Fjelldal PG, Hansen TJ, Karlsen Ø (2020) Effects of laboratory salmon louse infection on osmoregulation, growth and survival in Atlantic salmon. Conserv Physiol 8: coaa023

Fjørtoft HB, Besnier F, Stene A, Nilsen F and others (2017) The Phe362Tyr mutation conveying resistance to organophosphates occurs in high frequencies in salmon lice collected from wild salmon and trout. Sci Rep 7: 14258

Fjørtoft HB, Nilsen F, Besnier F, Stene A and others (2019) Salmon lice sampled from wild Atlantic salmon and sea trout throughout Norway display high frequencies of the genotype associated with pyrethroid resistance. Aquacult Environ Interact 11:459-468

Flaten AC, Davidsen JG, Thorstad EB, Whoriskey F and others (2016) The first months at sea: marine migration and habitat use of sea trout Salmo trutta post-smolts. J Fish Biol 89:1624-1640

Gargan P, Karlsbakk E, Coyne J, Davies C, Roche W (2016a) Sea lice (Lepeophtheirus salmonis and Caligus elongatus) infestation levels on sea trout (Salmo trutta L.) around the Irish Sea, an area without salmon aquaculture. ICES J Mar Sci 73:2395-2407

Gargan PG, Kelly FL, Shephard S, Whelan KF (2016b) Temporal variation in sea trout Salmo trutta life history traits in the Erriff River, western Ireland. Aquacult Environ Interact 8:675-689

* Gillibrand PA, Willis KJ (2007) Dispersal of sea louse larvae from salmon farms: modelling the influence of environmental conditions and larval behavior. Aquat Biol 1: 63-75

* Grimnes A, Jakobsen PJ (1996) The physiological effects of salmon lice infection on post-smolt of Atlantic salmon. J Fish Biol 48:1179-1194

Jensen AJ, Finstad B, Forseth T, Rikardsen A (2005) Sjøørret, sjørøye og klima. NINA Temahefte 31:55-61

* Jensen AJ, Finstad B, Fiske P, Hvidsten NA, Rikardsen AH, Saksgård L (2012) Timing of smolt migration in sympatric populations of Atlantic salmon (Salmo salar), brown trout (Salmo trutta), and Arctic char (Salvelinus alpinus). Can J Fish Aquat Sci 69:711-723

Johnsen IA, Fiksen Ø, Sandvik AD, Asplin L (2014) Vertical salmon lice behavior as a response to environmental conditions and its influence on regional dispersion in a fjord system. Aquacult Environ Interact 5:127-141

Johnsen IA, Asplin LC, Sandvik AS, Serra-Llinares RM (2016) Salmon lice dispersion in a northern Norwegian fjord system and the impact of vertical movements. Aquacult Environ Interact 8:99-116

Jonsson B (1985) Life history patterns of freshwater resident and sea-run migrant brown trout in Norway. Trans Am Fish Soc 114:182-194

Jonsson B, Jonsson N (2009) Migratory timing, marine survival and growth of anadromous brown trout Salmo trutta in the River Imsa, Norway. J Fish Biol 74:621-638

Jonsson B, Jonsson N, Brodtkorb E, Ingebrigtsen PJ (2001) Life-history traits of brown trout vary with the size of small streams. Funct Ecol 15:310-317

Karlsen Ø, Finstad B, Ugedal O, Svåsand T (eds) (2016). Kunnskapsstatus som grunnlag for kapasitetsjustering innen produksjonsområder basert på lakselus som indikator. Rapport fra Havforskningen 14-2016, Bergen

Klemetsen A, Amundsen PA, Dempson JB, Jonsson B, Jonsson N, O'Connell MF, Mortensen E (2003) Atlantic salmon Salmo salar L., brown trout Salmo trutta L. and Arc- tic charr Salvelinus alpinus (L.): a review of aspects of their life histories. Ecol Freshwat Fish 12:1-59

${ }^{*} L$ 'Abée-Lund JH, Jonsson B, Jensen AJ, Saettem LM, Heggberget TG, Johnsen BO, Næsje TF (1989) Latitudinal variation in life-history characteristics of sea-run migrant brown trout Salmo trutta. J Anim Ecol 58:525-542

KLiu Y, Olaussen JO, Skonhoft A (2011) Wild and farmed salmon in Norway - a review. Mar Policy 35:413-418

ㄴ. of sea trout post-smolts in a Norwegian fjord system. J Fish Biol 52:923-936

*MacCrimmon HR, Marshall TL (1968) World distribution of brown trout, Salmo trutta. J Fish Res Board Can 25: $2527-2548$

Mason IB (1982) A model for assessment of weather forecasts. Aust Meteorol Mag 30:291-303

* Middlemas SJ, Stewart DC, Mackay S, Armstrong JD (2009) Habitat use and dispersal of post-smolt sea trout Salmo trutta in a Scottish sea loch system. J Fish Biol 74: 639-651

Mohn AM, Vollset KW, Karlsbakk E (2020) Making the best of lousy circumstances: the impact of salmon louse Lepeophtheirus salmonis on depth preference of sea trout Salmo trutta. Aquacult Environ Interact 12:215-229

Myksvoll MS, Sandvik AD, Albretsen J, Asplin L and others (2018) Evaluation of a national operational salmon lice monitoring system-from physics to fish. PLOS ONE 13: e0201338

Myksvoll MS, Sandvik AD, Johnsen IA, Skarðhamar J, Albretsen J (2020) Impact of variable physical conditions and future increased aquaculture production on lice infestation pressure and its sustainability in Norway. Aquacult Environ Interact 12:193-204

* Naylor R, Hindar K, Fleming IA, Goldburg R and others (2005) Fugitive salmon: assessing the risks of escaped fish from net-pen aquaculture. Bioscience 55:427-437

Nevoux M, Finstad B, Davidsen JG, Finlay R and others (2019) Environmental influences of life history strategies in partial anadromous brown trout (Salmo trutta, Salmonidae). Fish Fish 20:1051-1082

* Peiman KS, Birnie-Gauvin K, Midwood JD, Larsen MH, Wilson AD, Aarestrup K, Cooke SJ (2017) If and when: intrinsic differences and environmental stressors influence migration in brown trout (Salmo trutta). Oecologia 184:375-384

Kabe B, Gallego A, Wolf J, Murray RO, Stuiver C, Price D, Johnson H (2020) Applied connectivity modelling at local to regional scale: the potential for sea lice transmission between Scottish finfish aquaculture management areas. Estuar Coast Shelf Sci 238:106716

Ruud T (2015) Space use and harvest selection of sea trout (Salmo trutta) living in a marine protected area: an acoustic telemetry study. MSc thesis, Norwegian University of Life Sciences, Ås

Salama NK, Collins CM, Fraser JG, Dunn J, Pert CC, Murray AG, Rabe B (2013) Development and assessment of a biophysical dispersal model for sea lice. J Fish Dis 36: 323-337

* Sandvik AD, Bjørn PA, Ådlandsvik B, Asplin L and others (2016) Toward a model-based prediction system for salmon lice infestation pressure. Aquacult Environ Interact 8:527-542

Sandvik AD, Johnsen IA, Myksvoll M, Sævik PN, Skogen MD (2020) Prediction of the salmon lice infestation pressure in a Norwegian fjord ICES J Mar Sci 77:746-756 
Sandvik AD, Bui $S$, Huserbråten $M$, Karlsen $\varnothing$, Myksvoll MS, Ådlandsvik B, Johnsen IA (2021) The development of a sustainability assessment indicator and its response to management changes as derived from salmon lice dispersal modelling. ICES J Mar Sci (in press)

Serra-Llinares RM, Bøhn T, Karlsen Ø, Nilsen R and others (2020) Impacts of salmon lice on mortality, marine migration distance and premature return in sea trout. Mar Ecol Prog Ser 635:151-168

Shephard S, MacIntyre C, Gargan P (2016) Aquaculture and environmental drivers of salmon lice infestation and body condition in sea trout. Aquacult Environ Interact 8: $597-610$

Skaala Ø, Kålås S, Borgstrøm R (2014) Evidence of salmon lice-induced mortality of anadromous brown trout (Salmo trutta) in the Hardangerfjord, Norway. Mar Biol Res 10:279-288

Skarðhamar J, Albretsen J, Sandvik AD, Lien VS and others (2018) Modelled salmon lice dispersion and infestation patterns in a sub-arctic fjord. ICES J Mar Sci 75: 1733-1747

Skoglund H, Vollset K, Barlaup BT, Lennox R (2019) Gytefisktelling av laks og sjøaure på Vestlandet: status og utvikling i perioden 2004-2018. LFI Uni Miljø Report 357, Bergen

Stien A, Bjørn PA, Heuch PA, Elston DA (2005) Population dynamics of salmon lice Lepeophtheirus salmonis on Atlantic salmon and sea trout. Mar Ecol Prog Ser 290: 263-275

Taranger GL, Svåsand T, Bjørn PA, Jansen PA and others (2012) Forslag til førstegenerasjons målemetode for miljøeffekt (effektindikatorer) med hensyn til genetisk påvirkning fra oppdrettslaks til villaks, og påvirkning av lakselus fra oppdrett på viltlevende laksefiskbestander. Rapport fra Havforskningsinstituttet no. 13-2012, Bergen

Taranger GL, Karlsen Ø, Bannister RJ, Glover KA and others (2015) Risk assessment of the environmental impact of

Editorial responsibility: Kate S. Hutson,

Nelson, New Zealand

Reviewed by: 3 anonymous referees
Norwegian Atlantic salmon farming. ICES J Mar Sci 72 : 997-1021

Thorstad EB, Finstad B (2018) Impacts of salmon lice emanating from salmon farms on wild Atlantic salmon and sea trout. NINA Report 1449:1-22

Thorstad EB, Økland F, Finstad B, Sivertsgård R, Plantalech N, Bjørn PA, McKinley RS (2007) Fjord migration and survival of wild and hatchery-reared Atlantic salmon and wild brown trout post-smolts. Hydrobiologia 582: 99-107

Thorstad EB, Todd CD, Uglem I, Bjørn PA and others (2015) Effects of salmon lice Lepeophtheirus salmonis on wild sea trout Salmo trutta-a literature review. Aquacult Environ Interact 7:91-113

Thorstad EB, Todd CD, Uglem I, Bjørn PA and others (2016) Marine life of the sea trout. Mar Biol 163:47

Urdal K (2013) Analysar av skjelprøvar frå Sogn og Fjordane i 2012. Rådgivende Biologer AS, rapport nr. 1728, Bergen

Urke HA, Haugen TO, Kjærstad G, Alfredsen JA, Kristensen $T$ (2018) Laks-og aurebestanden i Strynevassdraget: vandrings-mønsteret hjå laksesmolt og aure, ungfiskproduksjon og botndyr. Noregs miljø- og biovitskaplege universitet (NMBU), MINA fagrapport 48, Ås

Vollset KW, Krontveit RI, Jansen PA, Finstad B and others (2016) Impacts of parasites on marine survival of Atlantic salmon: a meta-analysis. Fish Fish 17:714-730

*Vollset KW, Dohoo I, Karlsen Ø, Halttunen E and others (2018) Food for thought: disentangling the role of sea lice on the marine survival of Atlantic salmon. ICES J Mar Sci 75:50-60

Wells A, Grierson CE, MacKenzie M, Russon IJ and others (2006) Physiological effects of simultaneous, abrupt seawater entry and sea lice (Lepeophtheirus salmonis) infestation of wild, sea-run brown trout (Salmo trutta) smolts. Can J Fish Aquat Sci 63:2809-2821

*Wendelaar Bonga SE (1997) The stress response in fish. Physiol Rev 77:591-625

Submitted: July 2, 2020

Accepted: December 23, 2020

Proofs received from author(s): April 14, 2021 